\title{
New records of aphyllophoroid fungi (Agaricomycetes, Basidiomycota) from the Les na Vorskle area of the Belogor'e Nature Reserve (Belgorod Region, Russia)
}

\author{
Sergey V. Volobuev ${ }^{1}$, Anton A. Logachev ${ }^{2}$, Nikolay V. Mushnikov', Mikhail V. Okun \\ ${ }^{1}$ Laboratory of Systematics and Geography of Fungi, Komarov Botanical Institute, Russian Academy of Sciences, \\ Professor Popov str., 2, St. Petersburg, 197376, Russia. E-mails: sergvolobuev@mail.ru, m.okun@hotmail.com, \\ ${ }^{2}$ Theodosius Dobzhansky Center for Genome Bioinformatics, St. Petersburg State University, Sredniy av., 41A, \\ St. Petersburg, 199034, Russia. E-mail: log_fungi@mail.ru, \\ ${ }^{3}$ University of Wyoming, 1000E University av., Laramie, WY, 82071, USA. E-mail: mushnickoff@gmail.com.
}

\begin{abstract}
Fifty-two species of aphyllophoroid fungi have been recorded for the first time from the Belogor'e Nature Reserve and from the Belgorod Region of Russia. An annotated list of records with data on substrate, habitat type and voucher numbers (LE, OHHI) is provided. Several rare and restrictedly distributed species in Europe are presented, viz. Hapalopilus croceus, Phellinus rimosus, Pseudomerulius aureus, Sarcoporia polyspora, and Skeletocutis odora. Two species, Gloeohypochnicium analogum and Granulobasidium vellereum, are proposed to be considered as indicators of biologically valuable broad-leaved forests in Eastern Europe.
\end{abstract}

Keywords: aphyllophoroid fungi, biodiversity, fungal distribution, reserve, Hapalopilus croceus

\section{INTRODUCTION}

Aphyllophoroid fungi represent an artificial nontaxonomic group in Agaricomycetes (Hibbett et al., 2014) which unites macromycetes with diverse morphology of fruiting bodies, including polypores, corticioids, clavarioids and hydnoids. These fungi implement different life strategies - from mainly saprotrophs on dead wood and litter to parasitic and ectomycorrhizal species (Kotiranta et al., 2009), and consequently they play an important role in forest ecosystems. At the same time, forest fragmentation takes place in many regions in Northern, Eastern, Central and Southern Europe (Christensen et al., 2005), and nature reserves are aimed to protect the biodiversity of different organism groups inhabiting vulnerable or unique environments.

The Les na Vorskle area is one of the oldest nature reserves in Russia. It was established in 1924 in the vicinity of the Borisovka settlement, on the northern side of Vorskla River, in the southern part of the Central Russian Upland. Nowadays, this territory is a part of the Belogor'e Nature Reserve (see Belgorod Region in Fig. 1), and covers a square of $10.4 \mathrm{~km}^{2}$.

Les na Vorskle territory lies on the foreststeppe vegetation zone and represents an upland forest with an expressed erosive relief, with gullies and ravines. The absolute elevation is from 135 to $217 \mathrm{~m}$ a. s. 1 . The climate in this zone is moderate continental, with a hot and prolonged summer and rather cold winter. The average temperature in January is $-8.1^{\circ} \mathrm{C}$ and $+19.9{ }^{\circ} \mathrm{C}$ in June. Winter temperature may go down until $-37^{\circ} \mathrm{C}$, while in summer it can reach up to $+40{ }^{\circ} \mathrm{C}$. Average sum of precipitation is $530 \mathrm{~mm}$ per year, and about half of it falls in summer. The basic soil-forming components are loess and loess-like loams. The grey forest soils are spread here (Neshataev et al., 1967).

The plant cover is composed of both natural forests, including coppice, and wood plantations. The 100-110-year old trees dominate, the

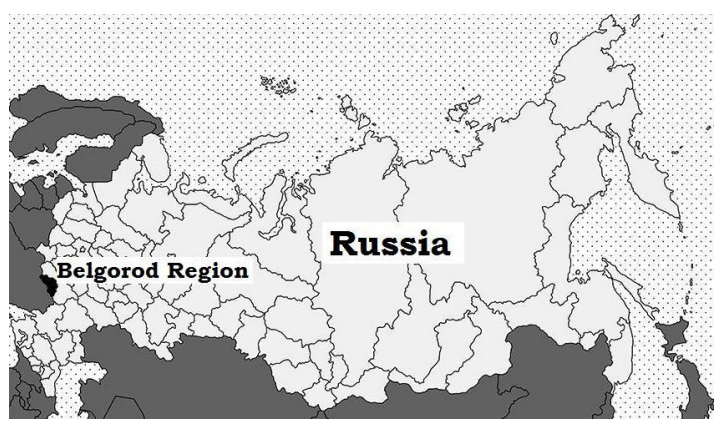

Fig. 1. The location of Belgorod region, Russia 
oak forests that are older than 300 years occupy about $1.6 \mathrm{~km}^{2}$, but they were seriously damaged during the Second World War (Shapovalov $\&$ Arbuzova, 2005). The main forest-forming trees are Quercus robur (about of $80 \%$ of wood territory), Acer platanoides, Tilia cordata and Fraxinus excelsior. In a recent research, the increasing role of Acer platanoides in local communities has been shown in this area (Ryabtsev et al., 2009). Cultivated Pinus sylvestris forests are 100-120 years old and are characterized by rather high proportion of broadleaved species, primarily of Tilia cordata and Acer platanoides. The underwood level is formed by single individuals of Euonymus europaea, E. verrucosa, and Acer campestre.

The key peculiarity of the current state of plant communities is the negative zoogenic influence of wild boar, roe deer and mouse-like rodents. According to the winter counting data (Smirnov et al., 2009; Chervonny \& Shchekalo, 2010), there are in average 22 individuals of boars and 25 roe deers per $1 \mathrm{~km}^{2}$ what means that the litter layer and soils are pretty much destroyed. Common species of the field layer are Aegopodium podagrarium, Asarum europaeum, Stellaris holostea, etc.

Aphyllophoroid fungi have never been a principal object of biodiversity studies in the Belogor'e Nature Reserve. Until now the data on species richness has been scattered in several publications devoted to inventories and ecology of fungal species (Brezhnev, 1950; Bondartsev, 1953; Bedenko, 1985; Nikolaev, 1986; Psurtseva et al., 2003). This article augments new data on aphyllophoroid fungi of this protected area.

\section{MATERIAL AND METHODS}

The fieldwork was carried out by the authors in August 2011 in the Belogor'e Nature Reserve $\left(50^{\circ} 36-37^{\prime} \mathrm{N}, 35^{\circ} 57-59^{\prime} \mathrm{E}\right)$. Data on locality, type of forest (according to the dominant classification) and host tree was recorded for each specimen. The dried material was identified by the first author using a LOMO Micmed 6 and a Carl Zeiss AxioImager A1 light microscopes as well as the standard set of chemicals $(5 \% \mathrm{KOH}$, Melzer's reagent, and Cotton Blue). Voucher specimens are deposited in the Mycological herbarium of the Komarov Botanical Institute of RAS, St. Petersburg (LE) and the mycological collection of the V.N. Khitrovo Herbarium of the Orel State University, Orel (OHHI). The nomenclature of corticioids follows Bernicchia \& Gorjón (2010), and that of polypores - Ryvarden \& Melo (2014), respectively.

\section{ANNOTATED LIST OF SPECIES}

ANTRODIA HETEROMORPHA (Fr.) Donk - on fallen trunk and branches of Acer platanoides, oak-maple and lime-tree-birch-oak forests (LE 302192, OHHI 1295).

AURISCALPIUM VULGARE Gray - on old cones of Pinus sylvestris, birch-pine forest (LE 303232).

BotRYoBASIDIUM INTERTEXTUm (Schwein.) Jülich \& Stalpers - on fallen trunk of Pinus sylvestris, pine forest (LE 302167).

Botryobasidium laeve (J. Erikss.) Parmasto on fallen trunks and logs of Quercus robur and Tilia cordata, lime-tree-birch-oak and maple-oak forest (LE 302196, LE 303238).

Botryobasidium MEDIUM J. Erikss. - on fallen trunk of Pinus sylvestris, pine forest (LE 303201).

Byssomerulius corium (Pers.) Parmasto - on dry log of Tilia cordata, maple-lime-tree-oak forest (LE 302177).

CERIPORIA PURPUREa (Fr.) Donk - on fallen log of Quercus robur, maple-lime-tree-oak forest (LE 303210).

DAEDALEOPSIS CONFRAGOSA (Bolton) J. Schröt. - on dry trunk of Salix sp., maple-lime-tree-oak forest (LE 302175).

DATRONIA MOLLIS (Sommerf.) Donk - on dry trunk of Acer platanoides, maple-lime-tree-oak forest (LE 303202).

DendRothele ACERINA (Pers.) P.A. Lemke - on bark of Acer platanoides, maple-oak forest (LE 302163).

GLOEOHYPOCHNICIUM ANALOGUM (Bourdot \& Galzin) Hjortstam - on fallen trunk of Quercus robur, oak-maple forest (LE 302166).

GLOEOPORUS Dichrous (Fr.) Bres. - on fallen log of deciduous tree, maple-lime-tree-oak forest (LE 302183).

GRANulobasidium VELLEREum (Ellis \& Cragin) Jülich - on dry log of Corylus avellana, mapleoak forest (LE 303229).

HaPAlOPILUS CROCEUS (Pers.) Donk - on dry trunk of Quercus robur, maple-oak forest (LE 302181) (Fig. 2). 


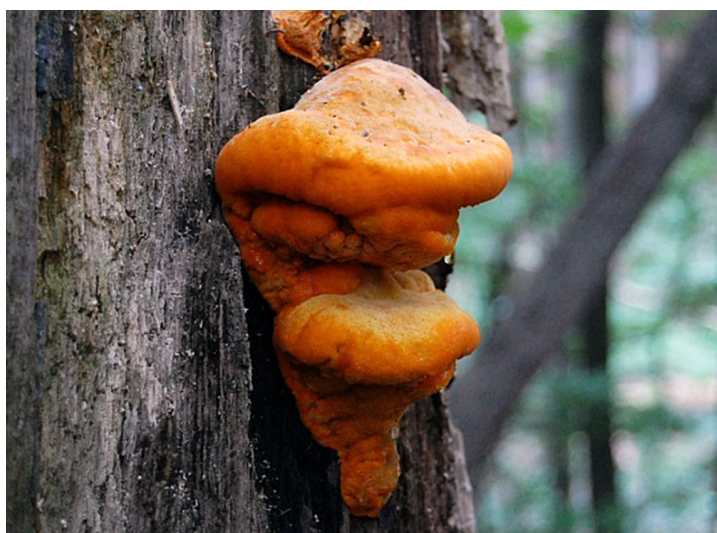

Fig. 2. Fruiting bodies of Hapalopilus croceus on dry standing oak tree. Photo by D. Latkin.

Hymenochaete cinnamomea (Pers.) Bres. - on fallen logs of Quercus robur, maple-oak forest (LE 303224, OHHI 1305).

Hyphoderma mutatum (Peck) Donk - on fallen trunks and dry logs of Acer platanoides and Tilia cordata, maple-oak and maple-limetree-oak forests (LE 303203, LE 303239, OHHI 1297).

Hyphoderma NEMORALE K.H. Larss. - on dry branch of Tilia cordata, maple-lime-tree-oak forest (LE 302195).

Hyphoderma SETigerum (Fr.) Donk - on fallen trunks and branches of Acer platanoides, Betula pendula and Quercus robur, limetree-birch-oak, maple-lime-tree-oak and maple-oak forests (LE 303218, LE 303243, OHHI 1304).

Hyphoderma tRAnsiens (Bres.) Parmasto - on dry trunk of Acer platanoides, maple-oak forest (LE 303226).

INONOTUS DRYADEUS (Pers.) Murrill - on butt of Quercus robur, maple-oak forest (LE 302184).

Oligoporus ALNi (Niemelä \& Vampola) Piątek - on fallen log of Quercus robur, maple-lime-treeoak forest (LE 302164).

Oligoporus Leucomallellus (Murrill) Gilb. \& Ryvarden - on fallen trunks of Pinus sylvestris pine and maple-oak-pine forests (LE 302198, OHHI 1296).

Oligoporus TEPHROLEUCUS (Fr.) Gilb. \& Ryvarden - on fallen logs and trunk of Acer platanoides and Quercus robur, maple-oak and maple-lime-tree-oak forest (LE 303225, LE 303245).
OXYPORUS CORTICOLA (Fr.) Ryvarden - on fallen trunks of Acer platanoides and Quercus robur maple-oak-pine, lime-tree-birch-oak and maple-lime-tree-oak forests (LE 302178, LE 302179, OHHI 1292).

Peniophora limitata (Chaillet ex Fr.) Cooke - on fallen trunk of Tilia cordata, lime-tree-pine forest (LE 302199).

Peniophora RUfomarginata (Pers.) Bourdot \& Galzin - on fallen log of Tilia cordata, maplelime-tree-oak forest (LE 303216).

Peniophora Violaceolivida (Sommerf.) Massee on dry branch of Acer platanoides, mapleoak forest (LE 303231).

Peniophorella praetermissa (P. Karst.) K.H. Larss. - on fallen trunk of Quercus robur, maple-oak forest (LE 303209).

Phanerochaete laevis (Fr.) J. Erikss. \& Ryvarden - on fallen branches of deciduous tree, limetree-birch-oak forest (LE 302197).

Phanerochaete tuberculata (P. Karst.) Parmasto - on fallen log of Acer platanoides, oak-maple forest (LE 303228).

Phellinus contiguus (Pers.) Pat. - on fallen trunk of Quercus robur, maple-oak forest (LE 302176).

Phellinus ferruginosus (Schrad.) Pat. - on fallen trunks of Acer platanoides and Quercus robur, maple-oak, lime-tree-birch-oak and maple-lime-tree-oak forests (LE 302185, LE 303235, OHHI 1293).

Phellinus Rimosus (Berk.) Pilát - on dry trunk of Acer platanoides, oak-maple forest (LE 303213).

POlYPORUS VARIUS (Pers.) Fr. - on dry trunk of Pyrus communis, orchard.

Pseudomerulius Aureus (Fr.) Jülich - on fallen trunk of Pinus sylvestris, pine forest (LE 302169).

RAMARIA ABIETINA (Pers.) Quél. - on litter, birchpine and maple-oak-pine forests ( $\mathrm{LE}$ 302161, LE 302162).

SARCODONTIA CROCEA (Schwein.) Kotl. - on dry trunk of Pyrus communis, orchard (LE 302180).

SARCOPORIA POLYSPORA P. Karst. - on fallen trunk of Pinus sylvestris, pine forest(LE 303208).

SCHIZOPORA FLAVIPORA (Berk. \& M.A. Curtis ex Cooke) Ryvarden - on fallen trunks and dry logs of Quercus robur, Corylus avellana and Acer platanoides, maple-lime-tree-oak and maple-oak forests (LE 302187, LE 303236, LE 303237, OHHI 1294). 
Schizopora RAdUla (Pers.) Hallenb. - on fallen trunk of Quercus robur, maple-lime-tree-oak and maple-oak forests (LE 303212, OHHI 1299).

Skeletocutis nivea (Jungh.) Jean Keller - on dry and fallen branches and logs of Acer platanoides and Tilia cordata, maple-limetree-oak, lime-tree-birch-oak and maple-oak forests (LE 303205, LE 303240, OHHI 1298).

Skeletocutis odora (Sacc.) Ginns - on fallen trunk of Pinus sylvestris, pine forest (LE 303207).

STECCHERINUm Fimbriatum (Pers.) J. Erikss. - on fallen log of Quercus robur, maple-lime-treeoak forest (LE 302186).

STECCHERINUm OCHRACEUm (Pers.) Gray - on fallen trunk of Quercus robur, maple-oak forest (LE 303206).

TRAMETES HIRSUTA (Wulfen) Lloyd - on dry trunk of Malus domestica, orchard (LE 302193).

TRAMETES SuAVEOLENS (L.) Fr. - on fallen trunk of Populus tremula, maple-lime-tree-oak forest (LE 303222).

TRECHISPORA COHAERENS (Schwein.) Jülich \& Stalpers - on fallen logs of Quercus robur, oak-maple and lime-tree-birch-oak forests (LE 302173, OHHI 1291).

TRICHAPTUM FUSCOVIOLACEUM (Ehrenb.) Ryvarden - on fallen trunk of Pinus sylvestris, pine forest (LE 302189).

TyRomyces Chioneus (Fr.) P. Karst. - on fallen log of Quercus robur, maple-lime-tree-oak forest (LE 302171).

XYlodon CRUstosus (Pers.) Chevall. - on fallen and dry branches of Quercus robur and Tilia cordata, maple-oak and lime-tree-birch-oak forests (LE 302182, LE 303234).

XYLODON NESPORI (Bres.) J. Erikss. \& Hjortstam - on fallen trunk of Pinus sylvestris, pine forest (LE 303204).

Xylodon SPathulatus (Schrad.) Kuntze - on fallen trunks of Pinus sylvestris, pine and limetree-pine forests (LE 303219, LE 303244).

\section{DISCUSSION}

All the 52 species of aphyllophoroid fungi were recorded for the first time for the territory of Les na Vorskle area and the Belogor'e Nature Reserve, as well as for the Belgorod Region. Most of the species were adapted to grow on dead wood of deciduous trees. 20 species belonged to the oak-associated aphyllophoroid fungi, and 14 species were registered on maple wood. Among them, the noteworthy records of Hapalopilus croceus and Phellinus rimosus were revealed on large-dimension dry standing trunks of Quercus robur and Acer platanoides, respectively. Hapalopilus croceus is red-listed in three regions of Russia and 11 countries of Europe (The Global Fungal..., 2015), and is associated with old-aged oak trees, which are declining throughout Europe. Phellinus rimosus is known predominantly from Southern Europe, Mediterranean Region, the Caucasus, and Middle Asia (Ryvarden \& Melo, 2014). Our finding in Belgorod Region expands slightly its known distribution northwards.

Attention is also paid on Gloeohypochnicium analogum and Granulobasidium vellereum, and their host and habitat requirements. The occurrence of these species also in other protected broad-leaved forests of the nemoral zone in European Russia is noteworthy. They grow on fallen trunks, logs and branches of Acer, Alnus, Quercus, Tilia, and Ulmus (Malysheva \& Malysheva, 2008; Bolshakov \& Zmitrovich, 2014; Popov \& Volobuev, 2014). Therefore Gloeohypochnicium analogum and Granulobasidium vellereum are considered as indicator species of biologically valuable deciduous forests in Eastern Europe.

Ten further species were recorded on Pinus sylvestris in forest plantations. In addition to widespread species, mostly associated with pine, like Auriscalpium vulgare, Botryobasidium medium, and Trichaptum fuscoviolaceum, there were also rare or occasional species, such as Pseudomerulius aureus, Sarcoporia polyspora, and Skeletocutis odora (Vlasák \& Kout, 2010; Ryvarden \& Melo, 2014; Baldoni et al., 2015). The occurrence of these species in forest-steppe confirms the significance of the host tree in the spatial distribution of aphyllophoroid basidiomycetes.

\section{ACKNOWLEDGEMENTS}

We are grateful to Dr. Heikki Kotiranta for attentive review and valuable comments. Our thanks are also addressed to Dmitry Latkin for his participance in the field trip and to Sergey Bolshakov for the help with the literature. The study was financially supported by the grant of the President of the Russian Federation for young candidates of sciences (MK-6345.2015.4). 


\section{REFERENCES}

Baldoni, D. B., Ortiz-Santana, B., Coelho, G., Antoniolli, Z. I. \& Jacques, R. J. 2015. Sarcoporia polyspora (Basidiomycota, Polyporales): a rare wood-decay fungus newly recorded from South America. Nova Hedwigia 100(1-2): 177-187.

Bedenko, E. P. 1985. To the flora of fungi-macromycetes of the Central European Upland. (In Russian). Novitates systematicae plantarum non vascularium 22: 110-114.

Bernicchia, A. \& Gorjón, S. P. 2010. Corticiaceae s. 1. Fungi Europaei, vol. 12. Ed. Candusso. 1009 pp.

Bolshakov, S. Yu. \& Zmitrovich, I. V. 2014. Aphyllophoroid fungi of Mordovia Reserve. (In Russian, English summary). Mikologiya $i$ fitopatologiya 48(5): 283-298.

Bondartsev, A. S.1953. The Polyporaceae of the European part of USSR and the Caucasus. (In Russian). Moscow, Leningrad. $1106 \mathrm{pp}$.

Brezhnev, I. E. 1950. A synopsis of mycoflora of the Les na Vorskle reserve. (In Russian). Proceedings of Leningrad society of naturalists 70(3): 263-287.

Chervonny, V. V. \& Shchekalo, M. V. 2010. The population of wild boars (Sus scrofa Linnaeus, 1758) in reservation "Belogor'e" and Okskyi reservation. (In Russian, English summary). Belgorod State University Scientific Bulletin. Ser. Natural sciences 10(3): 61-69.

Christensen, M., Hahn, K., Mountford, E., Ódor, P., Standovár, T., Rozenbergar, D., Diaci, J., Wijdeven, S., Meyer, P., Winter, S. \& Vrska, T. 2005. Dead wood in European beech forest reserves. Forest Ecology and Management 210: 267-282. http:/ /dx.doi.org/10.1016/j.foreco.2005.02.032

Hibbett, D. D., Bauer, R., Binder, M., Giachini, A. J., Hosaka, K., Justo, A., Larsson, E., Larsson, K. H., Lawrey, J. D., Miettinen, O., Nagy, L., Nilsson, R. H., Weiss, M. \& Thorn, R. G. 2014. Agaricomycetes. In: McLaughlin, D. J. \& Spatafora, J. W. (eds) The Mycota, vol. VII, Part A. Systematics and Evolution. Pp. 373-429.

Kotiranta, H., Saarenoksa, R. \& Kytövuori, I. 2009. Aphyllophoroid fungi of Finland. A check-list with ecology, distribution, and threat categories. Norrlinia 19: 1-223.

Malysheva, V. F. \& Malysheva, E. F. 2008. The higher Basidiomycetes in forest and grassland communities of Zhiguli. (In Russian, English summary). Moscow, St. Petersburg. 242 pp.
Neshataev, Yu. N., Petrov, O. V., Schastnaya, L. S. \& Khantulev, A. A. 1967. Les na Vorskle (brief nature-historical essay). (In Russian). Scientific notes of the Leningrad State University 331. Ser. Biological Sciences 4(50): 11-36.

Nikolaev, P. M. 1986. Mycoflora of oak in the Les na Vorskle reserve. (In Russian). In: Complex studies of biogeocoenoses of forest-steppe oakeries. Leningrad. Pp. 63-74.

Popov, E. S., Volobuev, S. V. 2014. New data on woodinhabiting macromycetes in key protected areas of the South-Western part of the Non-Chernozem zone. (In Russian, English summary). Mikologiya i fitopatologiya 48(4): 231-239.

Psurtseva, N. V., Belova, N. V. \& Ryabusheva, Yu. V. 2003. Macromycetes of the Belogor'e Nature reserve (Plot Les na Vorskle). Conservation ex situ. (In Russian, English summary). Mikologiya i fitopatologiya 37(6): 66-73.

Ryabtsev, I. S, Tikhodeeva, M. Yu. \& Ryabtseva, I. M. 2009. Under shelterwood regeneration of woody plants in oak-dominated (Quercus robur L.) broadleaf stands of different age. (In Russian, English summary). Saint-Petersburg University Bulletin. Ser. 3. Biology 2: 12-21.

Ryvarden, L. \& Melo, I. 2014. Poroid fungi of Europe. Oslo. 456 pp.

Shapovalov, A. S. \& Arbuzova, M. V. 2005. Consequences of the occupation in the period of Great Patriotic War for the Les na Vorskle reserve. (In Russian). In: Reserves during Great Patriotic War (1941-1945). Kursk. Pp. 22-29.

Smirnov, K. A., Zhemchuzhnikov, A. S. \& Nemchenko, V. A. 2009. Storage and ingestion of winter woody forage by roedeer (Capreolus capreolus) in oakeries of Belogor'e reserve. (In Russian). Zoologicheskiy zhurnal 88(5): 623-628.

The Global Fungal Red List Initiative. 2015. http:// iucn.ekoo.se/iucn/species_list/ (accessed 25.03.2015).

Vlasák, J. \& Kout, J. 2010. Sarcoporia polyspora and Jahnoporus hirtus: two rare polypores collected in South Bohemia, Czech Republic. Czech Mycology 61: 187-195. 
94 Folia Cryptog. Estonica 